\title{
RELATIONSHIPS BETWEEN MICROFIBRIL ANGLE, MODULUS OF ELASTICITY AND COMPRESSIVE STRENGTH IN Eucalyptus wood
}

\author{
Paulo Ricardo Gherardi Hein ${ }^{1 \oplus}$, José Tarcísio Lima ${ }^{1}$
}

\begin{abstract}
Many traits are known to be important in determining the value of Eucalyptus wood as sawn timber. The commercial importance of the microfibril angle (MFA) for wood quality is well established for a range of softwoods, but is less clear for hardwood species. For instance, the relationships of MFA with wood stiffness and compressive strength are unknown in Eucalyptus. Therefore, the aim of this study was to evaluate the correlation between MFA and the modulus of elasticity $\left(\mathrm{E}_{\mathrm{cotm}}\right)$ in compression parallel to grain and compressive strength $\left(\mathrm{F}_{\mathrm{c} 0 \mathrm{k}}\right)$ using juvenile wood of Eucalyptus grandis from fast-growing plantations. The correlation between wood stiffness and compressive strength was high (0.91). The cellulose microfibril angle presented a correlation of -0.67 with wood stiffness and of -0.52 with compressive strength in Eucalyptus juvenile wood. MFA was found to be important in determining the mechanical behaviour of wood and appears to be a useful parameter to indicate wood stiffness and strength in juvenile Eucalyptus from short-rotation plantations.
\end{abstract}

Keywords: MFA, stiffness, compressive strength, timber, variability.

\section{INTRODUCTION}

Over the past decade, many scientific contributions investigated the effects of the cellulose microfibril angle (MFA) on wood properties. MFA, the orientation of the crystalline cellulose in the secondary cell wall wood along the fibre axis has a predominant effect on wood stiffness (Cave 1966) and numerous studies have supported this argument through experimental data (Cave 1968, Donaldson 2008, Walker and Butterfield 1995, Downes et al.2002). It has been known that the stiffness and compressive strength of wood decreased as microfibril angle increased in wood (Walker and Butterfield 1995, Barnett and Bonham 2004). This trend appears to systematically occur in many genera.

MFA has also long been known to influence dimensional changes in wood with changes in moisture content (Meylan 1968, Yamamoto et al. 2001). According to Barnett and Bonham (2004), most shrinkage takes place transversely when the MFA is small and, as the MFA increases, the longitudinal component of the shrinkage increases in a highly non-linear manner. Such phenomenon is responsible for some degrade on drying; especially crook (Walker and Butterfield 1995).

Furthermore, many studies have demonstrated that cellulose microfibril angle can present correlation with fibre or tracheids length (Hirakawa and Fujisawa 1995, Kibblewhite et al. 2005, Tsutsumi et al. 1982), lignin content (Hori et al. 2003, Jungnikl et al. 2008), and spiral grain (Cown et al. 2004). However, the relationship of MFA with wood properties at what Kretschmann et al. (1998) have classified as "macroscopic level" is not fully understood and this is an area of active research.

\footnotetext{
${ }^{1}$ Ciência e Tecnologia da Madeira - Departamento de Ciências Florestais - Universidade Federal de Lavras - campus universitário - Lavras, Minas Gerais, Brazil - CEP 37200-000. 
The importance of MFA, as it relates to wood quality, is well established for softwoods, but is less clear for hardwoods (Donaldson 2008). In Eucalyptus wood, previous studies have investigated the relationship between MFA and mechanical traits indicating that MFA would be the prime determinant of wood stiffness. For instance, Evans and Ilic (2001) have concluded that the MFA was the major determinant of specific modulus (E by wood density) in Eucalyptus delegatensis wood using 104 samples. Yang and Evans (2003) have reported that MFA alone accounted for 87 percent of the variation in modulus of elasticity in Eucalyptus globulus, E. nitens and E. regnans. Hence, this ultrastructural feature of the wood cell wall seems to be important in improving overall products quality in Eucalyptus wood.

Relationships between wood traits play a major role on functional biology of the tree and on industrial utilization of the wood (Zobel and Van Buijtenen 1989). During the tree development, cambial activity may produce stiffer wood to support the ever-increasing stem weight, gravity forces and bending movements induced by winds and thunderstorm. Thus, the trees became able to grow upwards under adverse conditions by changing the characteristics of their cell walls. On the other hand, these variations can limit the industrial application of wood.

The correlations between MFA, wood stiffness and strength are important in trees from fastgrowing forests because most of the Eucalyptus plantations are grown to supply the pulp and paper industry with raw material of high quality. According to Evans et al. (1996), for example, the mechanical properties of the paper are strongly influenced by the strength and stiffness of the fibres from which it is formed.

There are few studies investigating the relationship between ultra-structural features of the cell wall and wood mechanical properties, especially in juvenile hardwood. Most investigations on the relationship between MFA and mechanical properties have been based on stiffness parameters, specially the modulus of elasticity obtained in bending test. MFA is also related to modulus of rupture (MOR) in wood samples of Pinus (Bendtsen and Senft 1986, Deresse et al. 2003) and Picea (Treacy et al. 2000). However, the findings concerning correlation between MFA and compressive strength are limited, especially in Eucalyptus. The aim of this study was to determine the relationship between MFA estimated by X-ray diffraction and the elasticity and strength to compression parallel to the fibres of juvenile Eucalyptus wood.

\section{MATERIAL AND METHODS}

\section{Wood Samples}

One hundred and twenty-five (125) samples of Eucalyptus grandis wood (78 months) from Curvelo, central Minas Gerais state ( $19^{\circ} 17^{\prime} \mathrm{S}, 42^{\circ} 23^{\prime} \mathrm{W}$, alt 230-500 m), managed for charcoal production (Plantar S.A.) were investigated in this study. Wood samples (defect free) measuring 100 L x $25 \mathrm{R}$ x $25 \mathrm{~T}$ mm with well-defined tangential, radial and transverse faces were cut from central boards of 10 clones and submitted to mechanical tests. Depending on the extent of the defects, 10 to 15 samples were cut from each central board.

Prior to the compression test and MFA measurements, the specimens were conditioned in a room set for $20^{\circ} \mathrm{C}$ and $60 \%$ relative humidity to maintain the equilibrium moisture content of $\sim 11 \%$.

\section{Compression test}

Modulus of elasticity $\left(\mathrm{E}_{\mathrm{c} 0 \mathrm{~m}}\right)$ and compressive strength $\left(\mathrm{F}_{\mathrm{c} 0 \mathrm{k}}\right)$ were determined in compression parallel to the fibres test according to ASTM (1997) standard using the procedure described in D 
143-94 (Standard Methods of Testing Small Clear Specimens of Timber). The tests were performed in an electromechanical universal testing machine (EMIC DL 30000, São José dos Pinhais, Paraná, Brazil) of $300 \mathrm{kN}$ capacity in traction-compression.

\section{$X$-ray diffraction pattern measurements}

After mechanical testing, tangential sections ( $2 \mathrm{~mm}$-tick) were cut from the tested samples and used for microfibril angle measurements. X-ray diffraction data were collected on a diffractometer (Gemini-S, Agilent Technologies, Yarnton, UK) with $\mathrm{CuK} \alpha$ radiation (Figure 1). Images were integrated between $2 \theta=21.5^{\circ}$ and $23.5^{\circ}$ along the whole $360^{\circ}$ azimutal interval to plot the intensity diagram of the (200) plane. An automatic procedure allowed the detection of the 200 peaks and their inflexion points. The $T$ parameter, as defined by Cave (1966), was measured as the half distance between intersections of tangents at inflexion points with the baseline. The results are given as the mean of values obtained for the two 200 peaks.

MFA were estimated from the X-ray diffraction patterns using the formula proposed by Yamamoto et al. (1993). The formula gives an estimation of the mean MFA of wood sample based on its $T$ value and is given by:

$$
M F A=1.575 \times 10^{-3} \times T^{3}-1.431 \times 10^{-1} \times T^{2}+4.693 \times T-36.19
$$

A single X-ray diffraction pattern was recorded on each sample. The estimated error of the repeatability of the $T$ parameter measurements was $3 \%$, on average, for $T$ ranging from $14^{\circ}$ to $29^{\circ}$ which correspond to \pm 0.6 degrees.

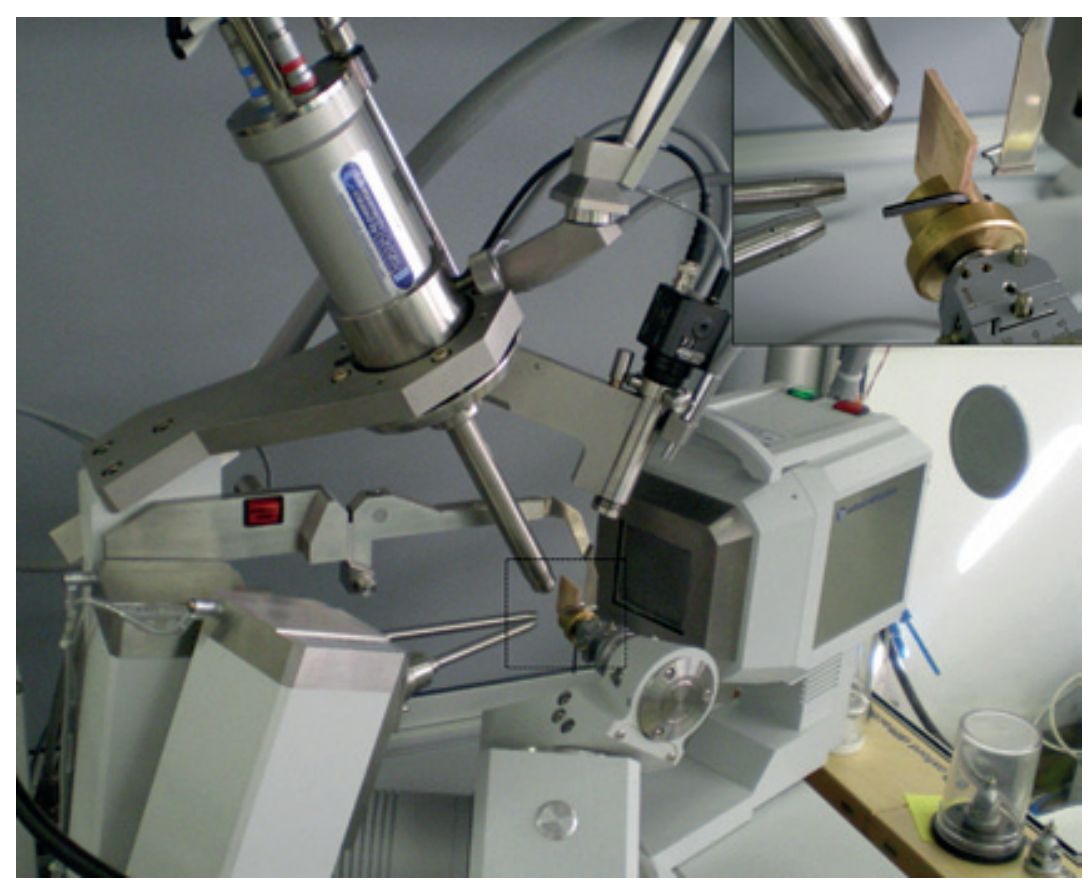

Figure 1. X-ray diffractometer device used for measuring XRD patterns. Top right: detail of the specimen holder and the $\mathrm{CuK} \alpha$ radiation gun. 


\section{RESULTS AND DISCUSSION}

\section{Characteristics of Eucalyptus juvenile wood}

Table 1 presents the statistical summary wood traits including modulus of elasticity, compressive strength, and microfibril angle of clear specimens of Eucalyptus. The wood samples used in this study presented, wood stiffness ranging from 4.5 to $11 \mathrm{GPa}$ and compressive strength ranging from 29 to $72 \mathrm{MPa}$. The cellulose microfibril angle within cell wall along the fibre axis varied from 8 to 23 degrees. Variability within the stem and between trees can have a negative impact for industrial applications where homogenous materials are required. Here, the variation range of wood stiffness and compressive strength (CV of $\sim 18 \%$ ) were lower than that of microfibril angle (CV of $\sim 23 \%$ ) and this variability is important because it allows the investigation of the correlation between fibre and wood characteristics.

Table 1. Descriptive statistics of modulus of elasticity $\left(\mathrm{E}_{\mathrm{c} 0 \mathrm{~m}}\right.$, in $\left.\mathrm{MPa}\right)$ and compressive strength $\left(\mathrm{F}_{\mathrm{c} 0 \mathrm{k}, \mathrm{i}}\right.$, in $\left.\mathrm{MPa}\right)$ of wood and microfibril angle (MFA, in degrees) of the fibres in samples of Eucalyptus grandis.

\begin{tabular}{lccc}
\hline & $\mathrm{E}_{\mathrm{c} 0, \mathrm{~m}}$ & $\mathrm{~F}_{\mathrm{c} 0, \mathrm{k}}$ & MFA \\
\hline Mean & 8,096 & 51.17 & 13.9 \\
Min. & 4,648 & 29.06 & 8.4 \\
Max. & 11,025 & 72.30 & 23.1 \\
CV $(\%)$ & 17.9 & 18.0 & 23.9 \\
\# of observations & 125 & 125 & 125 \\
\hline
\end{tabular}

The wood properties presented in table 1 are compatible to those found by similar studies on juvenile wood from Eucalyptus plantations. For instance, Moura (2000) has analyzed 10 hybrids of 9-years-old Eucalyptus presenting slightly higher mean modulus of elasticity (9159 MPa) and similar compressive strength parallel to grain (54.5 MPa) while Lima et al. (1999) have investigated of 8-years-old Eucalyptus wood finding lower values for compressive strength parallel to grain (42 MPa). Cruz et al. (2003) have evaluated Eucalyptus clones (at 5.5 and 10.5 years old) reporting compressive strength ranging from $40 \mathrm{MPa}$ to $52 \mathrm{MPa}$.

\section{Relationships between Eucalyptus wood traits}

MFA represents an important ultra-microscopical feature influencing the performance of wood products (Lima et al. 2004). Evans and Ilic (2001) and Yang and Evans (2003) have investigated the relationship between MFA and wood stiffness in Eucalyptus samples demonstrating that MFA was the prime determinant of the wood stiffness. If their findings can be generalized, MFA measurements should make possible the evaluation of the wood performance. Here, our experimental data show that the mean cellulose microfibril angle was negatively correlated to the stiffness $(r=-0,67)$ and compressive strength $(r=-0.52)$ of wood. The correlation between wood stiffness and compressive strength was 0.91 . 


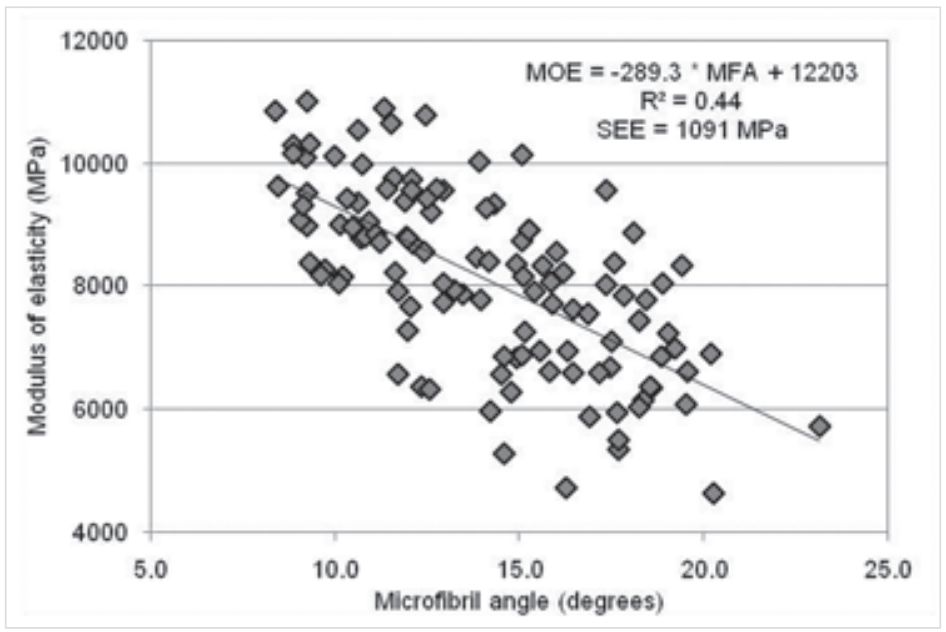

Figure 2. Relationship between wood stiffness and microfibril angle in Eucalyptus wood.

The predictions of the modulus of elasticity in compression parallel to grain from MFA are presented in figure 2. MFA variation accounted for 44 percent of the variation in modulus of elasticity in compression parallel to grain test.

Studies on softwoods have demonstrated the MFA and modulus of rupture (MOR) are correlated (Bendtsen and Senft 1986, Deresse et al. 2003, Treacy et al. 2000). However, the correlation between MFA and strength properties has been poorly reported in hardwoods. figure 3 presents the regression statistics for estimating compressive strength from microfibril angle.

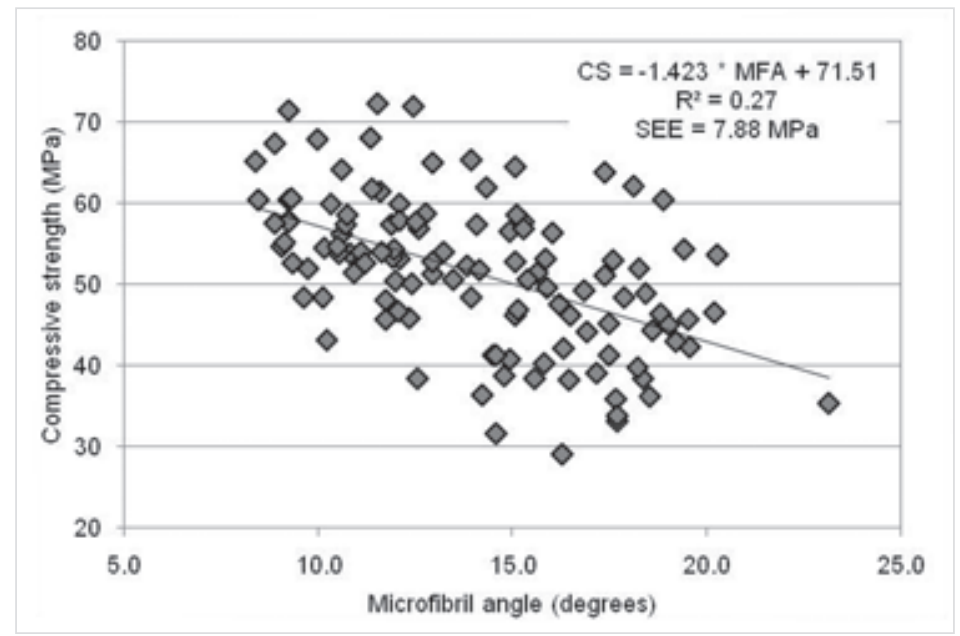

Figure 3. Relationship between compressive strength and microfibril angle in Eucalyptus wood.

Here, MFA variation accounted for only 27 percent of the variation in compressive strength (Figure 3). These relatively low correlations may be due the narrowed range of variation in MFA of Eucalyptus wood (from 8.5 to 23 degrees; in Pinus, MFA can vary from $\sim 5$ to $\sim 60$ degrees). For in- 
stance, the correlation between MFA and modulus of elasticity presented by Yang and Evans (2003) in Eucalyptus delegatensis were higher than that presented here. It is important to note that the range of variation of wood properties used by Yang and Evans (2003) was higher (stiffness decreased 3.5 times while MFA increased twofold). Moreover, we have investigated young wood samples (6.5 yearsold) while Yang and Evans (2003) have used wood samples with 15-33 years-old, and Evans and Ilic (2001) have examined mature wood (the age was not mentioned).

Although of the small magnitudes, the relationships presented in this study confirm that MFA, an ultra-structural feature of the cell wall, is useful for providing an indication of the wood stiffness and strength and therefore the wood quality.

\section{CONCLUDING REMARKS}

In this study, we have demonstrated that MFA could be used as a parameter for indicating elastic and strength properties of wood. MFA variation accounted for 44 percent of the variation in wood stiffness and 27 percent in compressive strength, even in juvenile wood. Although wood density has been considered the most important wood trait because it is well related to mechanical traits, our findings have demonstrated that MFA themselves are also important in determining the mechanical behaviour of Eucalyptus wood.

\section{ACKNOWLEDGMENTS}

The authors express their special thanks to the Plantar S.A. Company for providing material and to the Universidade Federal de Lavras (UFLA, Brazil), to the Centre de Cooperation Internationale en Recherche Agronomique pour le Development (CIRAD, UR 40 and AGAP, Montpellier, France) and to Centre National de la Recherche Scientifique (CNRS, MAB, Montpellier, France) and particularly to T Alméras and B Clair for supporting the experimental work. This study was partially funded by $\mathrm{CNPq}$ (Conselho Nacional de Desenvolvimento Científico e Tecnológico, Brazil) and FAPEMIG (Fundação de Amparo à Pesquisa do Estado de Minas Gerais).

\section{REFERENCES}

American Society for Testing and Materials - ASTM. Annual book of ASTM standards. Denvers: 1997. 679 p. D 143-94. Standard methods of testing small, clear specimens of timber. p. 23-53.

Barnett, J.R.; Bonham, V.A. 2004. Cellulose microfibril angle in the cell wall of wood fibres. Biological Reviews 79 (2):461-472.

Bendtsen, B.A.; Senft, J. 1986. Mechanical and anatomical properties in individual growth rings of plantation-grown eastern cottonwood and loblolly pine. Wood and Fibre Science 18 (1):23-38.

Cave, I.D. 1966. Theory of X-ray measurement of microfibril angle in wood. Forest Products Journal 16 (10):37-42.

Cave, I.D. 1968. The anisotropic elasticity of the plant cell wall. Wood Science and Technology 2 (4):268-278.

Cown, D.J.; Ball, R.D.; Riddell, M.J.C. 2004. Wood density and microfibril angle in 10 Pinus 
radiata clones: Distribution and influence on product performance. New Zealand Journal of Forest Science 34:293-315.

Cruz, C. R.; Lima, J. T.; Muniz, G. I. B. 2003. Variações dentro das árvores e entre clones das propriedades físicas e mecânicas da madeira de híbridos de Eucalyptus. Scientia Forestalis 64 (1):33-47.

Deresse, T.; Shepard, R.K.; Shaler, S.M. 2003. Microfibril angle variation in red pine (Pinus resinosa Ait.) and its relation to the strength and stiffness of early juvenile wood. Forest Products Journal $53(7 / 8): 34-40$.

Donaldson, L. 2008. Microfibril angle: measurement, variation and relationships - a review. IAWA Journal 29 (4):345-386.

Downes, G.M.; Nyakuengama, J.G.; Evans, R.; Northway, R.; Blakemore, P.; Dickson, R.L.; Lausberg, M. 2002. Relationship between wood density, microfibril angle and stiffness in thinned and fertilized Pinus radiata. IAWA Journal 23(3):253-265.

Evans, R.; Ilic, J. 2001. Rapid prediction of wood stiffness from microfibril angle and density. Forest Products Journal 51 (3):53-57.

Evans, R.; Stuart, S.A.; Van Der Touw, J. 1996. Microfibril angle scanning of increment cores by X-ray diffractometry. Appita Journal 49 (6):411.

Hirakawa, Y.; Fujisawa, Y. 1995. The relationship between microfibril angles of the S2 layer and latewood tracheid lengths in elite sugi tree (Cryptomeria japonica) clones. Journal Japanese Wood Research Society 41:123-131.

Hori, R.; Suzuki, H.; Kamiyama, T.; Sugiyama, J. 2003. Variation of microfibril angles and chemical composition: Implications for functional properties. J. Mat. Sci. Lett. 22: 963-966.

Jungnikl, K.; Koch, G.; Burgert, I. 2008. A comprehensive analysis of the relation of cellulose microfibril orientation and lignin content in the S2 layer of different tissue types of spruce wood (Picea abies(L.) Karst.). Holzforschung 62 (4):475-480.

Kibblewhite, R.P.; Evans, R.; Grace, J.C.; Riddell, M.J.C. 2005. Fibre length, microfibril angle and wood colour variation and interrelationships for two radiata pine trees with mild and severe compression wood. Appita J. 58 (4):316-322.

Kretschmann, D.E.; Alden, H.A.; Verrill, S. 1998. Variations of microfibril angle in loblolly pine: comparison of iodine crystallization and X-ray diffraction techniques. In: Butterfield, B.G., ed. Microfibril angle in wood. New Zealand: University of Canterbury. p.157-176.

Lima, J.T.; Breese, M.C.; Cahalan, C.M. 1999. Variation in compression strength parallel to the grain in Eucalyptus clones. Proceedings of the Fourth International Conference on the Development of Wood Science, Wood Technology and Forestry, Missenden Abbey, UK, 14-16 July 1999.

Lima, J.T.; Breese, M.C.; Cahalan, C.M. 2004. Variation in microfibril angle in Eucalyptus clones. Holzforschung 58 (2):160-166.

Meylan, B.A. 1968. Cause of high longitudinal shrinkage of wood. Forest Products Journal 18 (4):75-78. 
Moura, M.C.O. 2000. Variação em características do crescimento e da madeira em clones de Eucalyptus. Master Science, Universidade Federal de Lavras, Minas Gerais, Brasil. 63 pp.

Treacy, M.; Dhubha' in, A.N.; Evertsen, J. 2000. The influence of microfibril angle on modulus of elasticity and modulus of rupture in four provenances of Irish grown Sitka spruce (Picea sitchensis (Bong.) Carr). J. Inst. Wood Sci. 15:211-220.

Tsutsumi, J.; Matsumoto, T.; Kitahara, R.; Mio, S. 1982. Specific gravity, tracheid length and microfibril angle of sugi (Cryptomeria japonica D. Don): Seed grown trees compared with grafts. Bull. Kyushu Univ. For. 52: 115-120.

Walker, J.C.F.; Butterfield, B.G. 1995. The importance of microfibril angle for the processing industries. New Zealand Journal of Forestry 40 (4): 35-40.

Yamamoto, H.; Okuyama, T.; Yashida, M. 1993. Method of determining the mean microfibril angle of wood over a wide range by the improved Caves method. Mokuzai Gakkaishi 39:118-125.

Yamamoto, H.; Sassus, F.; Ninomiya, M.; Gril, J. 2001. A model of anisotropic swelling and shrinking process of wood. Part 2. A simulation of shrinking wood. Wood Science and Technology 35 (1):167-181.

Yang, J.L.; Evans, R. 2003. Prediction of MOE of eucalypt wood from microfibril angle and density. Holz als Roh- und Werkstoff 61 (6):449-452.

Zobel, B.J.; Van Buijtenen, J.P. 1989. Wood Variation: Its Causes and Control. Springer-Verlag, Berlin. 363 pp. 